\title{
Clusia criuva Cambess. (Clusiaceae): anatomical characterization, chemical prospecting and antioxidant activity
}

\section{KARLA M.M. DA SILVA ${ }^{1}$, ANDREA B. DA NÓBREGA ${ }^{2}$, BRUNO LESSA ${ }^{2}$, MARIA CAROLINA ANHOLETI ADRIANA Q. LOBÃO ${ }^{3}$, ALESSANDRA L. VALVERDE ${ }^{4}$, SELMA R. DE PAIVA ${ }^{3}$ and ANA JOFFILY ${ }^{3}$}

\author{
${ }^{1}$ Instituto de Pesquisas do Jardim Botânico do Rio de Janeiro, Rua Pacheco Leão, \\ 915, Jardim Botânico, 22460-030 Rio de Janeiro, RJ, Brazil \\ ${ }^{2}$ Fundação Oswaldo Cruz, Instituto de Tecnologia em Fármacos, Far-Manguinhos/FIOCRUZ, \\ Av. Comandante Guaranys, 447, Jacarepaguá, 22775-903 Rio de Janeiro, RJ, Brazil \\ ${ }^{3}$ Setor de Botânica, Departamento de Biologia Geral, Instituto de Biologia, Universidade Federal Fluminense, \\ Outeiro de São João Batista, s/n, Campus do Valonguinho, Centro, 24210-130 Niterói, RJ, Brazil \\ ${ }^{4}$ Lapromar, Departamento de Química Orgânica, Instituto de Química, Universidade Federal Fluminense, \\ Outeiro de São João Batista, s/n, Campus do Valonguinho, Centro, 24210-130 Niterói, RJ, Brazil
}

Manuscript received on June 2, 2016; accepted for publication on August 23, 2016

\begin{abstract}
This study aims the anatomical description and chemical characterization of aerial parts of Clusia criuva Cambess., Clusiaceae in addition to the evaluation of the antioxidant activity of crude extracts, correlated to the flavonoid content. The morphological characterization was performed using traditional techniques of plant anatomy. For phytochemical studies, crude extracts were obtained by static maceration and analyzed by thin layer chromatography. The antioxidant activity and the flavonoids content were determined by colorimetric methods involving, respectively, 2,2-diphenyl-1-picrylhydrazyl free radical and aluminum chloride. C. criuva has uniseriate epidermis, paracytic stomata, hypostomatic leaves, cuticular flanges and cordiform vascular cylinder with accessory bundles. Chemical prospecting confirmed the abundant presence of terpenes and phenols in the extracts of leaves and of fruits. The methanolic extract of seeds showed the lowest $\mathrm{EC}_{50}$ value, but the methanolic extract of pericarps exhibited the highest maximum antioxidant activity. The results suggested a high percentage of flavonoids in the hexanic extract of pericarps, however, this could represent, in fact, the presence of benzophenones. Secretory ducts and the shape of the midrib are diagnostic for $C$. criuva. The antioxidant activity is not directly related to the flavonoids. The results indicate the importance of future studies with $C$. criuva chemical constituents.
\end{abstract}

Key words: morphoanatomy, antioxidant activity, chemical prospecting, Clusia criuva, Clusiaceae, flavonoids.

\section{INTRODUCTION}

The genus Clusia (Clusiaceae) is represented by nearly 200 species (Judd et al. 2009), some of

Correspondence to: Karla Marins Mattos da Silva

E-mail: karlamariins@gmail.com which have been used as purgatives as well as germicides in the treatment of leprosy and skin infections, helping to heal wounds and the new borns navel. They have also been prescribed for the relief of headaches and used in veterinary medicine (Cavalcante and Frikel 1973, Coelho- 
Ferreira 2009, Valadeau et al. 2009, Odonne et al. 2013). Species of this genus are known as sources of poliisoprenylated benzophenones, terpenoids, benzoquinones and flavonoids (Andrade et al. 1998). Among the phenolic substances in Clusia, flavonoids, especially biflavonoids, may have particular importance in medicine (Chedier et al. 1999, Compagnone et al. 2008, Silva and Paiva 2012).

Studies involving plants have contributed very significantly in the search for new treatments for various diseases, showing effectiveness with several biological activities (Montanari and Bolzani 2001). The potential medicinal use of a species has a direct relationship to the metabolites that the plant produces for their own defence, that are usually characteristic of a species or a group of species. Therefore, detailed morphological, anatomical and biochemical studies are needed to identify the species and the chemical substances responsible for their potential biological activity. Such chemical and anatomical research is important to prevent the dangerous and inaccurate use of medicinal plants (Coelho et al. 2012).

Evidence that free radicals are involved in many degenerative diseases have increased interest in antioxidants, mainly of natural origin, as the current synthetic forms are restricted mainly due to their carcinogenic potential (Degáspari and Waszczynskyj 2004, Sousa et al. 2007).

The aim of this study was to perform the anatomic description of $C$. criuva leaves, the chemical prospecting of the crude extracts of the leaves and fruits, the evaluation of the antioxidant activity and determination of total flavonoids of these extracts. This will enhance the knowledge about this species adding to the potential for its use in medicine.

\section{MATERIALS AND METHODS}

\section{EQUIPMENT AND REAGENTS}

All solvents used were of analytical grade and obtained from VETEC, Brazil. The 2,2-diphenyl1-picrylhydrazyl (DPPH) and rutin were purchased from Sigma. The recordings were made by a UVVIS Biospectro spectrometer SP -220.

PLANT MATERIAL

Vegetative and reproductive parts of three pistillate individuals (collected numbers: SP08, SP09, SP10) of C. criuva were collected at Floresta Nacional da Tijuca. One voucher was deposited at the Jardim Botânico Herbarium, registered under the number RB 603158.

\section{ANALYSIS OF CELLULAR ORGANIZATION}

The middle of the petiole and leaf blade fragments were removed from the midrib, intercostal and edge regions of $C$. criuva leaves. The fragments were embedded in polyethylene glycol MW 1500 (PEG) proposed by Burger and Richter (1991). The sectioning was performed on a rotary microtome (RMC Products MT990) and sections stained with Astra Blue and Basic Fuchsin (Johansen 1940). The dissociation of the epidermis fragments was carried out by immersion in a solution of acetic acid and hydrogen peroxide (1:1) and subsequently the epidermal surfaces were stained with safranin. The already stained sections were made into semipermanent slides (50\% glycerin) for viewing and photography in a Zeiss Primo Star optical microscope. To characterize the leaf surface micromorphology, the samples were processed according to the usual technique for observation under scanning electron microscopy (SEM) (Klein et al. 2004). The epicuticular wax was classified according to Barthlott et al. (1998). 


\section{HISTOCHEMICAL ANALYSIS}

Freehand cut sections of freshly collected leaves were embedded in specific reagents for the identification of the following chemical classes: alkaloids (Dragendorff Solution), starch (Lugol), cellulose (Astra Blue), phenols (2\% Ferric Chloride), lipids (Sudam III and IV), lignin (Phloroglucinol), calcium oxalate (Sulfuric acid) and tannins (Chloridric vanillin), accordingly to SantAnna-Santos et al. (2006) with modifications.

\section{PROCESSING AND EXTRACTION OF PLANT} MATERIAL

Leaves and fruits (separated into pericarps and seeds) of dioecious individuals with pistillate flowers of C. criuva were dried at $40^{\circ} \mathrm{C}$, fragmented and submitted to static maceration using hexane and methanol as solvents. Three successive exchanges of solvent were made, followed by filtration of the extract and evaporation under reduced pressure.

\section{ANALYSIS OF CHEMICAL PROSPECTING}

Chemical analysis of the extracts were performed by Thin Layer Chromatography, adapted from Farnsworth (1966), Marini-Bettòlo et al. (1981) and Wagner et al. (1984). Dry extracts (50 mg) were solubilized in $1 \mathrm{~mL}$ of the respective solvent used in the extraction. To $300 \mu \mathrm{L}$ of each solubilized extract was added $1.2 \mathrm{~mL}$ of methanol. The results of applications to the chromatographic silica gel 60 G plates (Merck) were taken by a ATS4 and TLC Visualizer, controlled by WinCATS 1.4.4 software (Camag - Muttenz). The list of reagents used in chemical tests is presented in Table I.

TABLE I

List of reagents used in chemical prospecting tests by TLC (thin layer chromatography) (Farnsworth 1966, MariniBettòlo et al. 1981, Wagner et al. 1984).

\begin{tabular}{|c|c|c|}
\hline CHEMICAL CLASS & REAGENT & ELUENT \\
\hline Tannins and poliphenols & $\begin{array}{l}1 \% \text { Potassium ferrocyanide and } 2 \% \\
\text { ferric chloride }\end{array}$ & $\begin{array}{l}\text { Ethyl acetate: formic acid: acetic acid: water } \\
\qquad(100: 11: 11: 27)\end{array}$ \\
\hline Flavonoid glycosides & $\mathrm{NP} / \mathrm{PEG}$ & $\begin{array}{l}\text { Ethyl acetate: formic acid: acetic acid: water } \\
\qquad(80: 9: 9: 22) .\end{array}$ \\
\hline Flavonoid aglycones & NP/PEG & $\begin{array}{l}\text { Toluene: acetone: chloroform: } \\
\text { acetic acid }(40: 25: 35: 25)\end{array}$ \\
\hline Anthraquinone glycosides & $\begin{array}{l}5 \% \text { Methanolic solution of } 5 \% \\
\text { potassium hydroxide }\end{array}$ & $\begin{array}{l}\text { Ethyl acetate: formic acid: acetic acid: water } \\
\qquad(80: 9: 9: 22)\end{array}$ \\
\hline Anthraquinone aglycones & $\begin{array}{l}5 \% \text { Methanolic solution of } 5 \% \\
\text { potassium hydroxide }\end{array}$ & Toluene: acetone: chloroform $(25: 10: 10)$. \\
\hline Triterpenes and Steroids & Liebermann-Burchard & Hexane: ethyl acetate $(80: 20)$. \\
\hline Coumarins & $\begin{array}{l}5 \% \text { Methanolic solution of } 5 \% \\
\text { potassium hydroxide }\end{array}$ & Toluene: ethyl ether: acetic acid (30:30:30). \\
\hline Saponins & Anisaldehyde sulfuric & Chloroform: methanol: water $(64: 50: 10)$ \\
\hline Cardioactive glycosides & Keddes Reagent & Ethyl acetate: methanol: water $(84: 11: 8)$ \\
\hline Alkaloids & Dragendorff Reagent & Ethyl acetate: methanol: water $(40: 10: 20)$. \\
\hline Proanthocyanidins & $50 \%$ Sulfuric acid & $\begin{array}{l}\text { Ethyl acetate: formic acid: acetic acid: water } \\
(100: 11: 11: 27)\end{array}$ \\
\hline
\end{tabular}




\section{TOTAL ANTIOXIDANT ACTIVITY TEST}

Total antioxidant activity (TAA) of the extracts of $C$. criuva was evaluated by the scavenging of 2,2-diphenyl-1-picrylhydrazyl (DPPH) radical according to the methodologies described by Mensor et al. (2001) and Rufino et al. (2007), with modifications proposed by Silva and Paiva (2012). Solutions of the extracts with concentrations of $250,125,50,25,10$ and $5 \mu \mathrm{g} / \mathrm{ml}$ were prepared using methanol as solvent. To aliquots of 2.5 $\mathrm{mL}$ of each solution was added $1 \mathrm{ml}$ of DPPH solution $(0.3 \mathrm{mM}$ in methanol) and the mixture was homogenized on a vortex agitator. It was used 2.5 $\mathrm{mL}$ of methanol with $1 \mathrm{~mL}$ of DPPH solution as negative control and $2.5 \mathrm{ml}$ of each extract solution with $1 \mathrm{~mL}$ of methanol as blank. The absorbance was read at $518 \mathrm{~nm}$ at every 5 minutes for 30 minutes. The final absorbance was used to calculate the concentration of sample able to reduce in $50 \%$ the initial concentration of DPPH $\left(\mathrm{EC}_{50}\right)$, expressed as grams of sample / grams of DPPH (Rufino et al. 2007). It was used rutin as positive control and the procedures were performed in triplicate.

\section{DETERMINATION OF TOTAL FLAVONOIDS}

The content of total flavonoids, expressed as flavonols and flavones, was determined in extracts of $C$. criuva using a colorimetric method involving reaction with aluminum chloride, using rutin as a standard, as described by Chang et al. (2002) with modifications.

\section{STATISTICAL PROCESSING OF DATA}

The results were expressed as the mean \pm standard deviation of three independent experiments performed in triplicate. Statistical significance of the differences observed between different assays for the same sample and among the different samples were assessed using ANOVA (simple analysis of variance). In case of rejection of the null hypothesis by ANOVA, the Tukey-Kramer test was used.
The correlation between $\mathrm{EC}_{50}$ values of the crude extracts of $C$. criuva, the maximum antioxidant activity and the percentage corresponding to the flavonoid content (expressed as flavones and flavonols) were analysed and classified using the Pearson correlation coefficient (Cohen 1988, Filho and Junior 2009).

\section{RESULTS}

\section{ANALYSIS OF CELLULAR ORGANIZATION}

\section{Petiole}

In cross section, the middle region of the petiole of C. criuva has a plan-convex shape (Fig. 1a). The epidermis is uniseriate, glabrous and thick, has cuticle with flanges and internal periclinal, cutinized cell walls. Underlying the adaxial epidermis, 2-3 chlorophyll parenchyma layers are present, followed by fundamental parenchyma. On the abaxial surface, there are 10-12 layers of ring collenchyma (Fig. 1b) and the cells near the epidermis contain chloroplasts. Toward the vascular system fundamental parenchyma and idioblasts are present. The vascular system is composed of 30-35 cordiform bundles fused together, and are surrounded by perivascular fiber groups. In the phloem, the transport elements and companion cells occur in clusters, separated by parenchyma. The xylem is composed of proto- and meta-xylem elements, arranged in a radial series, separated by parenchyma cells. In the region corresponding to the medulla, isodiametrical parenchyma cells of varying sizes occur (Fig.1a).

\section{Leaf blade}

In front view, the epidermis is glabrous on both sides. The cells are polygonal shaped, slender with straight anticlinal walls on the upper side and slightly sinuous walls on the abaxial surface (Fig. 1c). Epicuticular wax "smooth layer" type, registered under electron microscopy, forms 

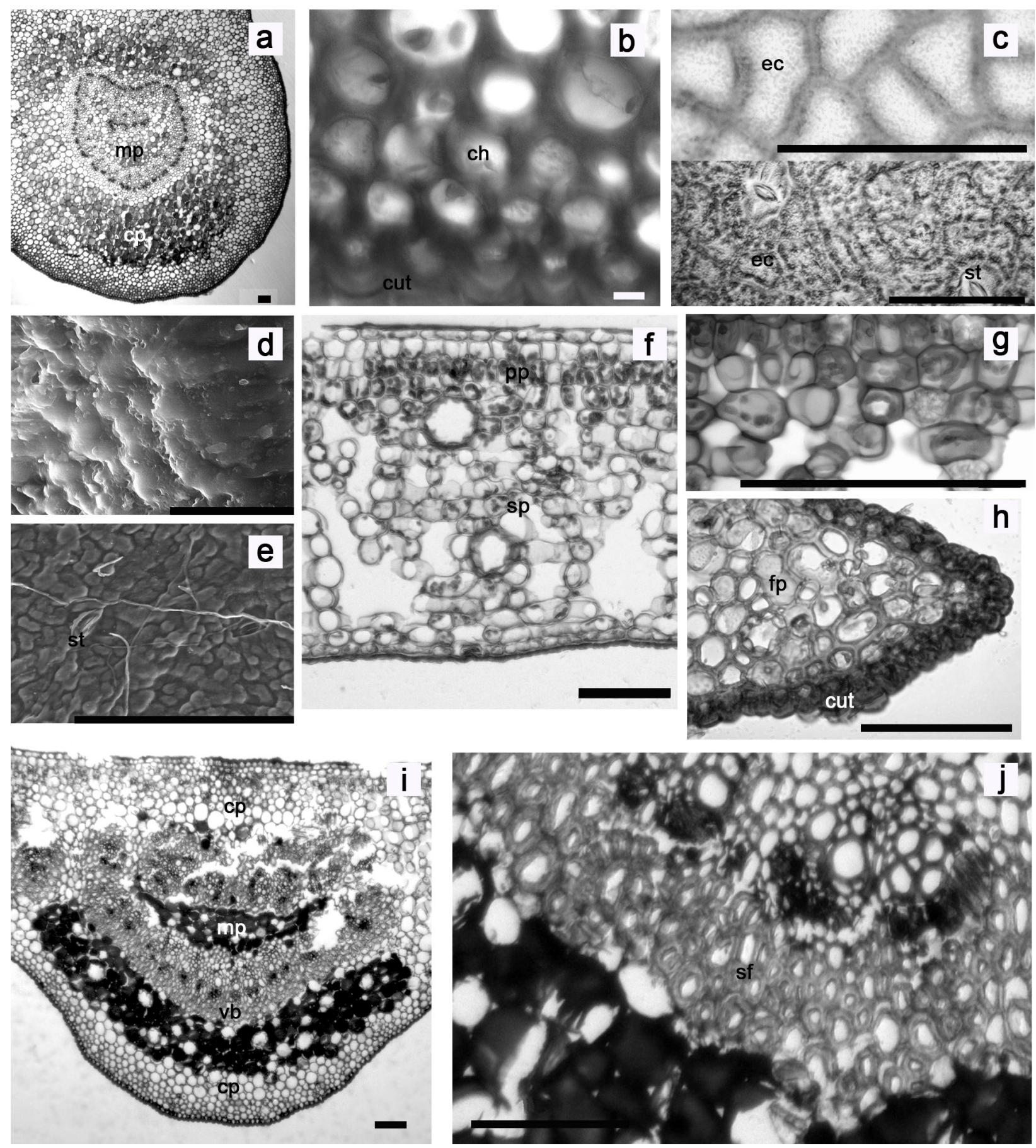

Figure 1 - Leaf anatomy of $\boldsymbol{C}$. criuva. a: Overview of the petiole cross-sectional; b: Abaxial face of the epidermis, showing the cuticular flanges and the collenchyma ring; $\mathbf{c}$ : Adaxial and abaxial face of the epidermis, showing paracytic stomata; d: Detail of cuticle in adaxial surface of the epidermis in scanning electron microscopy; e: Detail of cuticle on the abaxial surface of the epidermis in scanning electron microscopy; f: Overview of the mesophyll; $\mathbf{g}$ : Intermediate layer showing elongated cells and intercellular spaces; $\mathbf{h}$ : Detail of edge of leaf, showing the cuticular flanges and impregnation of internal periclinal wall; $\mathbf{i}$ : Overview of the midrib; $\mathbf{j}$ : Details of vascular bundles of the midrib. mp: Medullary parenchyma; cp: Cortical parenchyma; ch: Collenchyma; cut: Cuticle; ec: Epidermal cells; st: Stomata; pp: Palisade parenchyma; sp: Spongy parenchyma; fp: Fundamental parenchyma; vb: Vascular bundles; sf: Sclerenchyma fibers. Scale bar $=100 \mu \mathrm{m}$, except in Fig. 1d (Scale bar $=5 \mu \mathrm{m})$. 
a continuous coat on the leaf surface without prominent protrusions (Fig. 1d and 1e). The leaves are hypostomatic with paracytic stomata. The subsidiary cells, in general, are far larger than the guard cells and stomata are on the same level as the other epidermal cells. Transverse sections show that the epidermis is uniseriate, covered with smooth cuticle and less thickened when compared to other parts of the leaf, and penetrates between the anticlinal walls. The mesophyll of $C$. criuva is dorsiventral (Fig. 1f). The palisade parenchyma has 2-3 layers of elongated cells of similar size. Between the palisade and spongy parenchyma are 1-2 layers of loose tissue formed by rounded or slightly elongated cells (Fig. 1g). The spongy parenchyma is loose with large intercellular spaces, with 10-12 layers of cells with isodiametric format and with little variation in size. The vascular tissue is composed of bundles, with xylem towards the upper side and phloem at the abaxial surface. The bundles are surrounded by perivascular fibers.

At the end of the leaf margin the epidermis is uniseriate with elongated cells, with smooth cuticle and more thickened when compared to other parts of the leaf, with flanges and internal periclinal cutinized cell walls. The layers underlying the epidermis are occupied by cells of the fundamental parenchyma (Fig. 1h).

In the transverse plane of the leaf blade, at the midrib level, the epidermis is uniseriate and glabrous. In this region, the cuticle has characteristics similar to those observed in the petiole (Fig. 1i). Underlying the epidermis at the upper side, 2-3 chlorophyll parenchyma layers are presents, followed by fundamental parenchyma cells that increase in size towards the vascular cylinder. Along the abaxial surface, 3-5 layers of collenchyma of the annular type are observed which, in turn, are followed by 7-15 layers of parenchyma cells. The vascular system is formed by 30-37 fused bundles that are arc-shaped with invaginated ends. Along the cord parenchyma, there are 5-7 accessory bundles with the region facing the phloem at the abaxial surface. The vascular tissue has the same organization described for the petiole. Groups of perivascular phloem fibers occur along the entire length of tissue of the vascular system forming a sclerenchymatic sheath (Fig. 1j).

Idioblasts are also found in all parts, filled with organic compounds or containing calcium oxalate crystals in the form of druse, the latter being more common (Fig. 2a and 2b). Secretory structures formed by the schizogenous process result in secretory cavities of varying sizes, with 9-14 rectangular epithelial cells. The secretory cavities are abundant in the leaf of $C$. criuva, mainly in collenchymatic tissue, fundamental parenchyma of the petiole and midrib, parenchyma underlying the edge of the epidermis on edge, and intercostal region (Fig. 2b).

\section{ANALYTICAL HISTOCHEMISTRY}

Positive results for the possible presence of alkaloids were obtained in the parenchyma of the cortex and medulla of the petiole (Fig. 2c), in the midrib and in the palisade parenchyma of the intercostal region. Starch grains were seen in all parts of the leaf, especially in the cortical and medullar parenchyma of the petiole, the midrib near the vascular cylinder, the parenchyma near the epidermis of the petiole and midrib, and in the palisade parenchyma of the intercostal region (Fig. 2d). The presence of cellulose was confirmed, except in the cuticle and in the conducting tissue fibers. Phenols were detected in the parenchyma of the petiole, the midrib (Fig. $2 \mathrm{e}$ ), and in the intercostal region (mainly the palisade parenchyma). In the cuticle, the more conspicuous edge because this structure is thicker in relation to other parts of the sheet (Fig. 2f), lipophilic substances were detected in the walls of the underlying epidermal cells in certain parts of the sheet, in many idioblasts present in the cortical and medullary parenchyma of the petiole and midrib, 
and in the phloem vessels and parenchyma present in all parts of the sheet. Lignin was detected in the sclerenchyma fibers forming a sheath around the vascular bundles in the leaf blade (Fig. 2g), and in the vessel elements of all parts of the plant. Tannins were observed in the parenchyma of the petiole and midrib (Fig. 2f) and conductive elements of these same parts of the plant. The presence of numerous calcium oxalate crystals in the form of druse was confirmed throughout the leaf lamina and petiole.

Analysis of chemical prospecting

Table II summarizes the results for the chemical prospecting tests by thin layer chromatography (TLC).

\section{EVALUATION OF ANTIOXIDANT ACTIVITY}

The $\mathrm{EC}_{50}$ values obtained for extracts of C. criuva and the standard rutin are shown in Table III. Results are expressed as mean \pm standard deviation of three independent experiments. The curves obtained by linear regression showed a good coefficient of determination, according to Mensor et al. (2001) (R2>0.80), for all extracts. The statistical treatment of the data by ANOVA showed that for each extract (except for the hexanic extract of pericarps), there was no significant difference $(p>0.05)$ between the three independent assays. For the hexanic extract of pericarps only two independent assays were considered. Table III shows that all of C. criuva crude extracts exhibited $\mathrm{EC}_{50}$ values greater than

TABLE II

Detection of different chemical classes of extracts of $C$. criuva by TLC.

\begin{tabular}{|c|c|c|c|c|c|c|}
\hline $\begin{array}{ll}\text { CHEMICAL } \\
\text { CLASSES }\end{array}$ & CCLH & $\mathrm{CCPH}$ & $\mathrm{CCSH}$ & CCLM & CCPM & CCSM \\
\hline Tannins and poliphenols & - & - & - & - & + & + \\
\hline Flavonoid glycosides & - & - & - & + & + & - \\
\hline Flavonoid aglycones & - & - & - & - & + & + \\
\hline Anthraquinone glycosides & - & - & - & - & - & - \\
\hline Anthraquinone aglycones & - & - & - & - & + & - \\
\hline Triterpenes and Steroids & + & + & + & + & + & + \\
\hline Coumarins & - & - & - & - & - & + \\
\hline Saponins & - & - & - & + & + & + \\
\hline Cardioactive glycosides & - & - & - & + & + & - \\
\hline Alkaloids & - & - & - & + & + & + \\
\hline Proanthocyanidins & - & - & - & - & + & + \\
\hline
\end{tabular}

CCLH: crude hexanic extract of leaves; CCPH: crude hexanic extract of pericarps; CCSH: crude hexanic extract of seeds; CCLM: crude methanolic extract of leaves; CCPM: crude methanolic extract of pericarps; CCSM: crude methanolic extract of seeds.

- absence of the substance;

+ presence of the substance. 


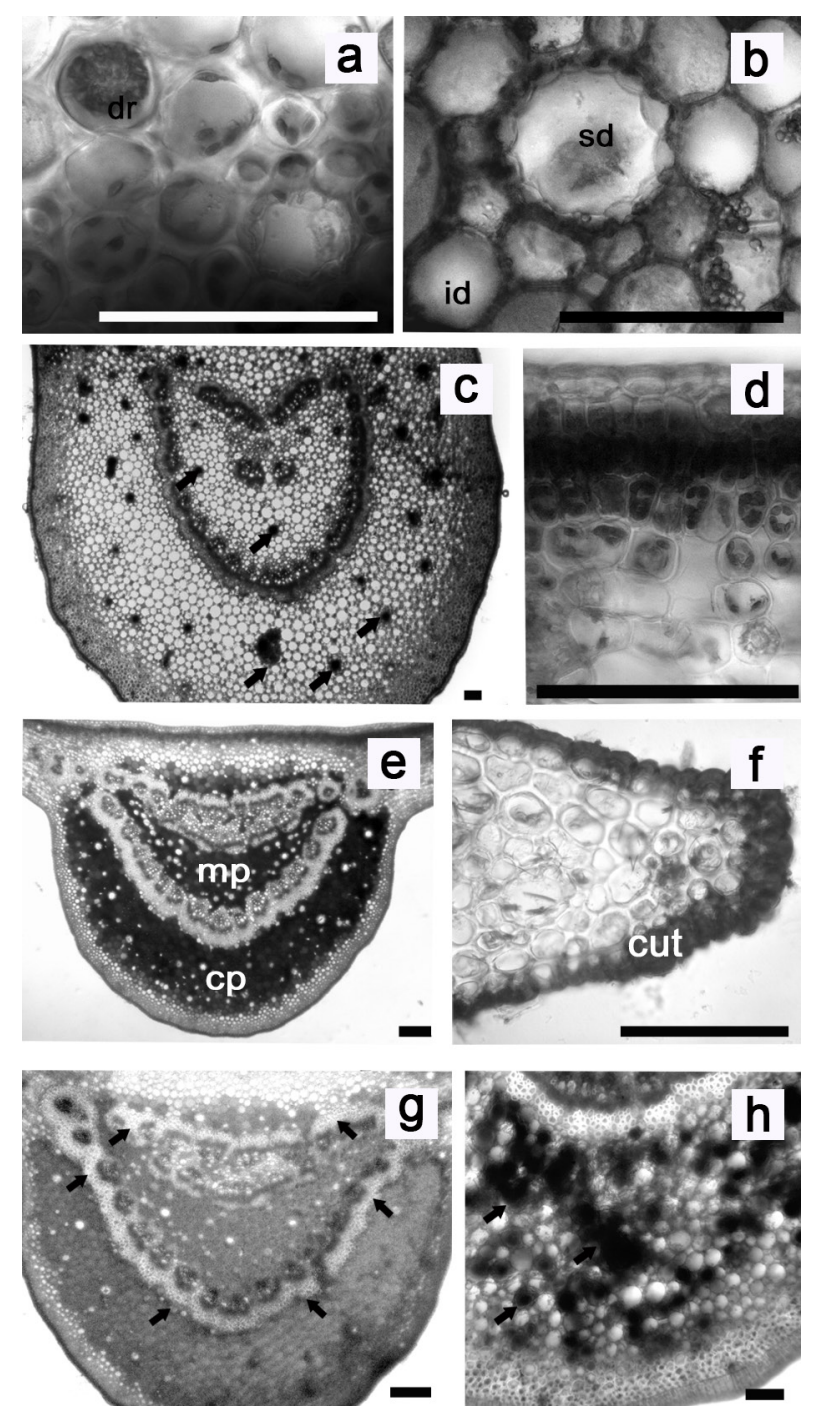

Figure 2 - Anatomy and histochemistry of $C$. criuva. a: Secretory duct and druse in the collenchyma ring of the midrib; b: Secretory cavity in the cortical parenchyma of the petiole; c: Overview of the petiole stained with the Dragendorff reagent; d: Starch grains in chlorophyllian parenchyma of the intercostal space; e: Overview of the midrib stained with ferric chloride; f: Overview of the leaf edge stained with Sudan III; g: Overview of the midrib stained with phloroglucinol, showing sclerenchyma fibers around the vascular cylinder; $\mathbf{h}$ : Midrib stained with hydrochloric vanillin, structures containing tannins are indicated by arrows. mp: Medullary parenchyma; cp: Cortical parenchyma; cut: Cuticle; sd: Secretory ducts; id: Idioblasts; dr: Druse. Scale bar $=100 \mu \mathrm{m}$, except in Fig. 1D (Scale bar $=5 \mu \mathrm{m})$. that found for the standard rutin. However, the Tukey-Kramer statistical test suggests that there was no significant difference between the $\mathrm{EC}_{50}$ values of rutin and the extracts analyzed, except when compared with the hexanic extract of leaves.

The kinetic profiles of reactions between DPPH and extracts of C. criuva and also with the standard rutin are shown in Figure 3. The analyses show that the reaction kinetics of all extracts had almost instantaneous responses for every concentration tested. In Fig. 3a, the standard rutin reached its maximum antioxidant activity at a concentration of $25 \mu \mathrm{g} / \mathrm{ml}$, at 10 to 15 minutes, resulting in about $98 \%$ of the maximum antioxidant activity. Among the extracts, the methanolic extract of seeds showed the lowest $\mathrm{EC}_{50}$ value (Fig. $3 \mathrm{~g}$ ), but the extract that showed the largest percentage of maximum antioxidant activity was the methanolic extract of pericarps, which at a concentration of $250 \mu \mathrm{g} /$ $\mathrm{ml}$, resulting in approximately $4.5 \%$ of remaining DPPH (Fig. 3f). Leaf extracts showed the lowest antioxidant activities in terms of both $\mathrm{EC}_{50}$ values and maximum antioxidant activity especially the hexanic extract which showed an $\mathrm{EC}_{50}$ value higher than the standard and the other extracts analyzed.

\section{DETERMINATION OF TOTAL FLAVONOIDS}

Table III presents the values of total flavonoid content obtained for extracts of C. criuva. Results are expressed as mean \pm standard deviation of three independent experiments. The statistical treatment of the data by ANOVA showed that three independent experiments for each extract were statistically equivalent ( $p \geq 0.05$ ). The results suggest the highest percentages of flavones and flavonols in the hexanic extracts. The hexanic extract of pericarps had the highest percentage of flavonoids among the tested extracts $(14.62 \pm$ $0.76 \%$ ), followed by the hexanic extract of leaves $(4.78 \pm 0.17 \%)$. These results were not expected, since flavonoids usually exhibits polar character 

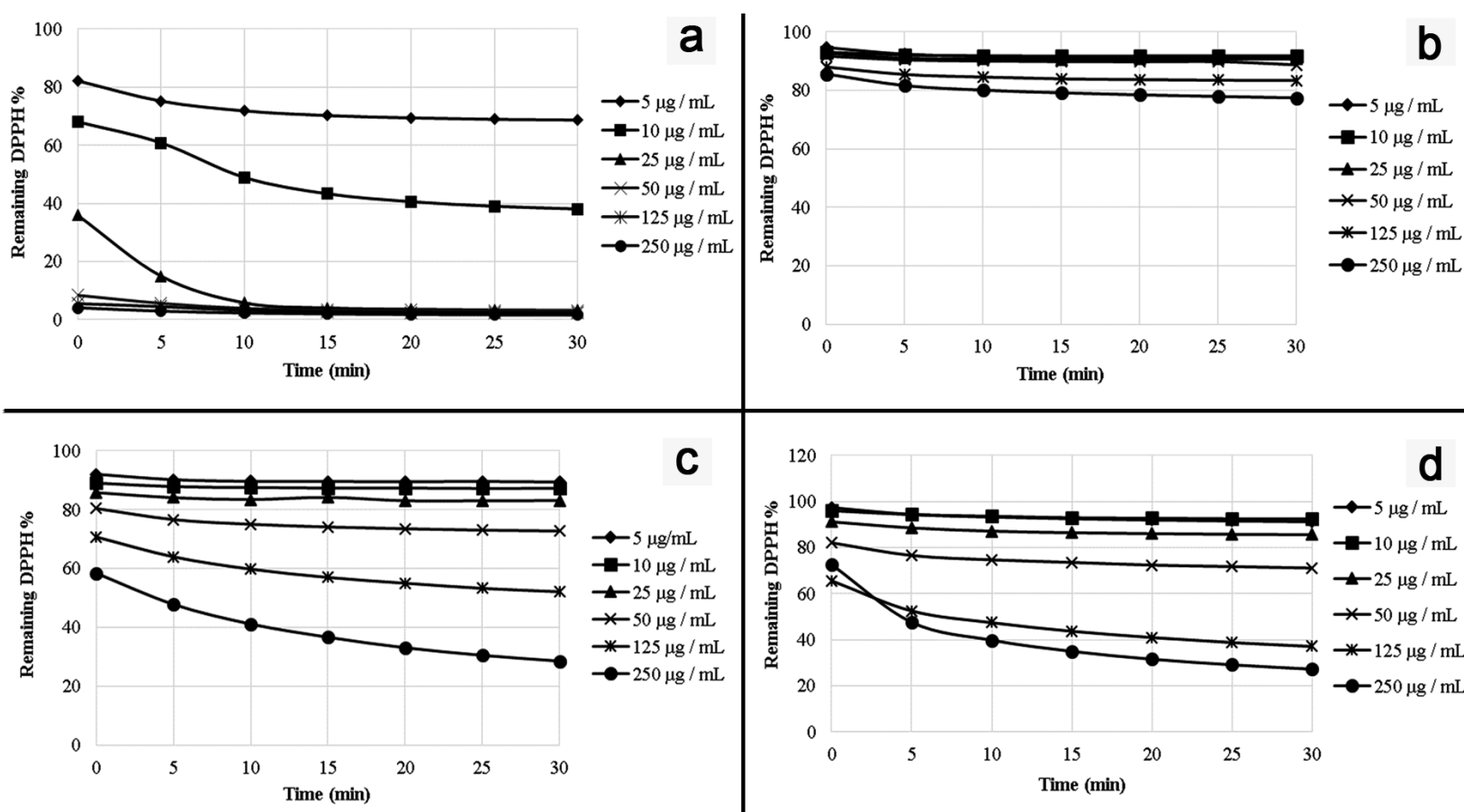

C
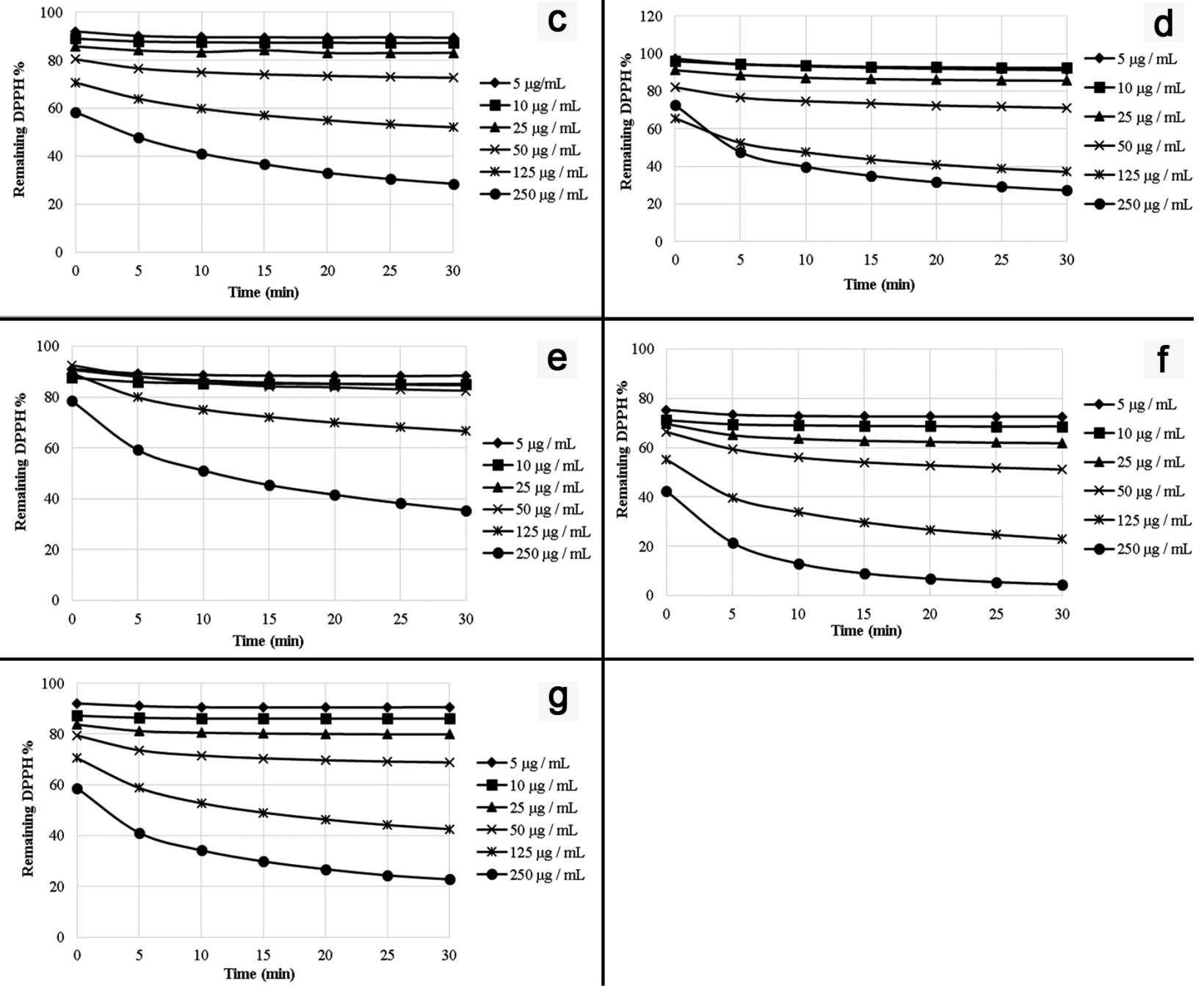

Figure 3 - Reaction kinetics with DPPH (2,2-diphenyl-1-picrylhydrazyl). (a) Rutin. (b) CCLH: crude hexanic extract of leaves. (c) $\mathrm{CCPH}$ : crude hexanic extract of pericarps. (d) $\mathrm{CCSH}$ : crude hexanic extract of seeds. (e) CCLM: crude methanolic extract of leaves. (f) CCPM: crude methanolic extract of pericarps. (g) CCSM: crude methanolic extract of seeds. 
TABLE III

Content of total flavonoids (flavones and flavonols), $\mathrm{EC}_{50}$ and maximum antioxidant activity (MAA) of $C$. criuva extracts.

\begin{tabular}{cccc}
\hline Samples & $\begin{array}{c}\text { Flavonoids } \\
\text { \% } \\
\text { Mean } \pm \text { SD }\end{array}$ & $\begin{array}{c}\mathbf{E C}_{\mathbf{5 0}}(\mathbf{M e a n} \pm \mathbf{S D}) \\
(\mathbf{g} \text { extract/ } \mathbf{g} \text { DPPH) }\end{array}$ & $\begin{array}{c}\text { \% } \\
\text { MAA }\end{array}$ \\
\hline CCLH & $4.78 \pm 0.17$ & $34.66 \pm 19.42$ & 22.60 \\
CCPH & $14.62 \pm 0.76$ & $10.94 \pm 0.36$ & 71.43 \\
CCSH & $3.14 \pm 0.16$ & $8.32 \pm 0.30$ & 72.75 \\
CCLM & $1.57 \pm 0.14$ & $12.54 \pm 1.43$ & 64.52 \\
CCPM & $0.63 \pm 0.12$ & $5.01 \pm 0.16$ & 95.49 \\
CCSM & $1.40 \pm 0.19$ & $4.06 \pm 1.12$ & 77.23 \\
Rutin & - & $0.61 \pm 0.11$ & 98.91 \\
\hline
\end{tabular}

CCLH: crude hexanic extract of leaves. CCPH: crude hexanic extract of pericarps. CCSH: crude hexanic extract of seeds. CCLM: crude methanolic extract of leaves. CCPM: crude methanolic extract of pericarps. CCSM: crude methanolic extract of seeds.

and are not present in hexanic extracts, as observed in TLC analysis. In order to understand what might be happening, possible interactions between the reagent used in this assay and the other chemical classes occurring in these extracts were studied.

\section{CORRELATION BETWEEN ANTIOXIDANT}

ACTIVITY AND FLAVONOID PERCENTAGE

The correlation between $\mathrm{EC}_{50}$ values of the crude extracts and the percentage of flavonoid content showed a coefficient of +0.1728 , indicating a weak positive correlation. It means that there is a tendency that high values of $\mathrm{EC}_{50}$ are associated with high percentages of flavonoids in the extracts. By definition the $\mathrm{EC}_{50}$ represents the concentration of sample able to reduce in $50 \%$ the initial concentration of DPPH, so, the best samples are those with the lowest values of $\mathrm{EC}_{50}$. Based on that, the results show that the extracts with best antioxidant activities were not the ones with the highest levels of flavonoids.

This data is corroborated by the correlation between the maximum antioxidant activity of extracts and the flavonoid content, which showed a coefficient of -0.1729 , indicating a weak negative correlation. It suggests that for Clusia criuva extracts there is not a direct relationship between antioxidant activity and the presence of flavonoids.

\section{DISCUSSION}

Clusia criuva anatomical presents characteristics considered common to Clusiaceae as uniseriate epidermis, paracytic stomata, hypostomatic leaves, presence of cuticular flanges, dorsiventral mesophyll, among others (Metcalfe and Chalk 1950, Stevens 2007).

Some authors also consider the presence of hypodermis in Clusiaceae a hallmark for the family. The hypodermis is a subepidermal layer, which originates in the meristem, that works as a storer tissue of water, and it is mostly found in xerophytes (Esau 1974). The presence of subepidermal layers has been mentioned in several studies about Clusia (Paula 1976, Schneider 1985, Silva et al. 2005, Fernandes 2007). However, in this study it was not observed the presence of these layers, possibly because the individuals were collected in Floresta Atlântica, where the climate is more humid than the habitats of C. criuva from studies cited earlier. This indicates a plasticity regarding the presence of subepidermal layers, showing that this feature is not essential to species. Fernandes (2007) reports that the presence of a storer tissue of water, in fact, is not essential. Since plants of some specific areas are not exposed to long droughts, and when it occurs, it can be an adaptation to periods of lowrainfall.

Fernandes (2007), Guimarães et al. (2013), Rocha et al. (2014) and Silva et al. (2014) also cite secretory ducts and cavities for species of Clusia. Paula (1976) notes the presence of schizogenous and schizolisigenous ducts in Clusia aff. macropoda. Although there are not ontogenesis studies for secretory structures found in Clusia, Fernandes (2007) indicates the absence of traces of lysis of epithelial cells and suggests that the 
observed structures have schizogenous origin. The development of sheath sclerenchyma fibers involving the vascular bundles was also mentioned in Clusia (Paula 1976, Boeger and Wisniewski 2003). According to Esau (1974), sclereids are cells sclerenchyma constituents presenting variety in shape and having thick lignified secondary wall with numerous pits. Edwards et al. (2000) point out the possibility for the appearance of sclerophylly in forest plants: adaptation to seasonal water deficits, the adaptation or consequence of living soils with low nutrients and emphasis longevity leaf, assisting in their leaf protection (defense against herbivores) or increasing leaf carbon gain per unit of investment. Such assumptions are not deleted and contribute to clarify the presence of sclerophyllous vegetation in tropical forest (Boeger and Wisniewski 2003).

Fernandes (2007) shows the format of the main vein as a distinctive anatomical character among the species of the genus Clusia. This structure, in C. criuva has a plan-convex format with rounded abaxial face. The vascular bundles present cordiform disposition with accessory bundles, which can differentiate it from other species.

The presence of alkaloids was detected by histochemical tests and confirmed in chemical prospecting of leaves. These substances can act as factors against herbivory - as well as calciumoxalate and control of pathogens (Wittstock and Gershenzon 2002).

Starch grains and lignin are widely present in plants. Starch is the main reserve substance of plant and lignin is the mainly heteropolymer present in cell walls of vascular plant cells (Opsahl and Benner 1995, Amaral et al. 2007).

Lipids detected in leaves of C. criuva are also substances widely present in plants. They have structural functions, constituting membranes and cuticular waxes (Barthlott et al. 1998, Moreau et al. 1998). Essential oils and resins are considered lipids that have been indicated in Clusia (Nogueira et al. 2001, Ferreira et al. 2014). In the chemical prospecting, were detected triterpenes and steroids. Possibly, terpenoids detected in the methanolic extracts have intermediate polarity, such as the terpenes acids, as described in Clusiaceae family (Tavares et al. 2001, Noldin et al. 2006, Guimarães et al. 2008). The terpenoids are substances in essential oils (mono- and sesquiterpenes) and latex - characteristic of Clusia according to Metcalfe and Chalk (1950). In some species of Clusia, triterpenes have been isolated from epicuticular wax (Medina et al. 2004, 2006).

Although the result for polyphenols had been negative to leaves in chemical prospecting test, phenols stood out in histochemical tests and is widely present. The group of phenols include various substances such as simple phenols, phenolic acids, coumarins, flavonoids and tannins, among others (Sousa et al. 2007). Several studies indicate the presence of phenols in Clusia (Seo et al. 1999, Compagnone et al. 2008, Silva and Paiva 2012, Ferreira et al. 2014). The presence of tannins, polyphenols and flavonoids were also confirmed to extracts from pericarp and seeds of C. criuva. Oliveira et al. (2012) highlights biflavonoids in fruits of $C$. paralicola. in flowers of Clusia, benzophenones have stood out, especially poliisoprenylated benzophenones (Oliveira et al. 1996, 1999, Lokvam et al. 2000, Porto et al. 2000, Compagnone et al. 2008, Silva et al. 2012).

The antioxidant potential of plant extracts is shown in some studies related to the flavonoid content (Peng et al. 2003, Proestos et al. 2006, Oliveira et al. 2012, Silva and Paiva 2012). This relationship is based on the fact that the chemical structure of flavonoids favours the reduction of free radicals by proton donation (Van Acker et al. 1996, Pietta 2000, Amić et al. 2003, Seyoum et al. 2006). In Silva and Paiva (2012) and Oliveira et al. (2012), species of Clusia show potent antioxidant activity in crude extracts, especially for fruit extracts as observed in this work. Silva and Paiva (2012) indicates a potential directly proportional to 
the flavonoid content described for crude extracts of $C$. fluminensis, concluding the possibility of a positive correlation between the two parameters. Oliveira et al. (2012), emphasizes that crude extracts of Clusia paralicola may have a better potential antioxidant activity compared to isolated flavonoids, biflavonoids in this case, which could be explained if the substances present in crude extracts are acting in synergy, or the activity of the crude extracts are related to another substance that has a controlling action relative to the other.

It was observed, according to the method used, a higher content of flavonoids, expressed as flavones and flavonols, in the hexanic extracts of $C$. criuva. This result led us to speculate the possible interaction between the aluminum chloride and benzophenones, which could be influencing the results obtained (Sancho et al. 2003). Thus, that high values of the flavonoid content in hexanic extracts may represent; in fact, the presence of benzophenones. Virginio (2015), supports a flavonoid content of $6.22 \pm 0.91 \%$ for the ethanolic extract of the female flower of Clusia lanceolata, however the literature does not indicate the presence of flavonoids in Clusia flowers, which are composed mainly by poliisoprenylated benzophenones, fatty acids and terpenes (Nogueira et al. 2001, Guimarães et al. 2013).

The result of anatomical characterization, chemical prospecting and analysis of the potential antioxidant activity involving leaves and fruits of $C$. criuva described in this paper are related to biological activities suitable for the species, expanding knowledge about its pharmacological, morphological and chemical potential. The results highlight the importance of conducting isolation studies, purification and identification of its chemical constituents. In conclusion, the data can assist taxonomic studies within the genus Clusia and/or the Clusiaceae family, since they indicate important anatomical characteristics of the species C. criuva.

\section{ACKNOWLEDGMENTS}

We thank Pós-Graduação em Ciência e Biotecnologia of the Universidade Federal Fluminense, the funding agencies Coordenação de Aperfeiçoamento de Pessoal de Nível Superior (CAPES), Conselho Nacional de Desenvolvimento Científico e Tecnológico (CNPq) and Programa de Fomento à Pesquisa da Universidade Federal Fluminense (FOPESQ-UFF) and the Laboratório de Produtos Naturais Marinhos - UFF, the use of facilities. We thank also Dr. Norman Rattclife for the English review.

\section{REFERENCES}

AMARAL LIV, GASPAR M, COSTA PMF, AIDAR MPM AND BUCKERIDGE MS. 2007. Novo método enzimático rápido e sensível de extração e dosagem de amido em materiais vegetais. Hoehnea 34: 425-431.

AMIĆ D, DAVIDOVIĆ-AMIĆ D, BEŠLO D AND TRINAJSTIĆ N. 2003. Structure-radical scavenging activity relationships of flavonoids. Croat Chem Acta 76: 55-61.

ANDRADE MR, ALMEIDA EX AND CONSERVA LM. 1998. Alkyl chromone and other compounds from Clusia nemorosa. Phytochemistry 47: 1431-1433.

BARTHLOTT W, NEINHUIS C, CUTLER D, DITSCH F, MEUSEL I, THEISEN I AND WILHELMI H. 1998. Classification and terminology of plant epicuticular waxes. Bot J Linn Soc 126: 237-260.

BOEGER MRT AND WISNIEWSKI C. 2003. Comparação da morfologia foliar de espécies arbóreas de três estádios sucessionais distintos de Floresta Ombrófila Densa (Floresta Atlântica) no Sul do Brasil. Rev Bras Bot 26: 61-72.

BURGER LM AND RICHTER HG. 1991. Anatomia da madeira, São Paulo: Editora Nobel.

CAVALCANTE PB AND FRIKEL P. 1973. A farmacopéia tiriyó/ Estudo étno-botânico, Belém: Gráfica Falangola Editora LTDA.

CHANG CC, YANG MH, WEN HM AND CHERN JC. 2002. Estimation of total flavonoid content in propolis by two complementary colorimetric methods. J Food Drug Anal 10: 178-182.

CHEDIER LM, PAIVA SR, MAZZEI L, FIGUEIREDO MR AND KAPLAN MAC. 1999. Comparative methodology for isolation of flavonoid glycosides from Clusia criuva Cambess. J High Res Chrom 22: 527-530. 
COELHO VPM, LEITE JPV, NUNES LG AND VENTRELLA MC. 2012. Anatomy, histochemistry and phytochemical profile of leaf and stem bark of Bathysa cuspidata (Rubiaceae). Austral J Bot 60: 49-60.

COELHO-FERREIRA M. 2009. Medicinal knowledge and plant utilization in an Amazonian coastal community of Marudá, Pará State (Brazil). J Ethnopharmacol 126: 159175.

COHEN J. 1988. Statistical Power Analysis for the Behavioral Sciences, $2^{\text {nd }}$ ed., Hillsdale, NJ: Erlbaum.

COMPAGNONE RS, SUAREZ AC, LEITÃO SG AND DELLE MONACHE F. 2008. Flavonoids, benzophenones and a new euphane derivative from Clusia columnaris Engl. Rev Bras Farmacogn 18: 6-10.

DEGÁSPARI CH AND WASZCZYNSKYJ N. 2004. Propriedades antioxidantes de compostos fenólicos. Visão Acadêmica 5: 33-40.

EDWARDS C, READ J AND SANSON G. 2000. Characterising sclerophylly: some mechanical properties of leaves from heath and forest. Oecologia 123: 158-167.

ESAU K. 1974. Anatomia das plantas com sementes, São Paulo: Blucher.

FARNSWORTH NR. 1966. Biological and phytochemical screening of plants. J Pharm Sci 55: 225-276.

FERNANDES SDC. 2007. Morfologia, anatomia, histoquímica e aspectos fisiológicos da lâmina foliar de espécies de Clusia (Clusiaceae). Tese de Mestrado, Universidade de Brasília, Brasil. (Unpublished).

FERREIRA RO, JUNIOR ARC, SILVA TMG, CASTRO RN, SILVA TMS AND CARVALHO MG. 2014. Distribution of metabolites in galled and non-galled leaves of Clusia lanceolata and its antioxidant activity. Rev Bras Farmacogn 24: 617-625.

FILHO DBF AND JÚNIOR JAS. 2009. Desvendando os mistérios do coeficiente de correlação de Pearson. Rev Pol Hoje 18: 115-146.

GUIMARÃES AG, SANTOS MM, BISPO RM, MACHADO SMF, RIBEIRO AS, MORAES VRS, FERREIRA AG AND LEÃO KV. 2008. Triterpenos pentacíclicos de Clusia sellowiana (Clusiaceae). In: Livro de resumos da $31^{\text {a }}$. Reunião Anual da Sociedade Brasileira de Química v. PN273.

GUIMARÃES ALA, BIZARRI CHB, BARBOSA LS, NAKAMURA MJ, RAMOS MFS AND VIEIRA ACM. 2013. Characterisation of the effects of leaf galls of Clusiamyia nitida (Cecidomyiidae) on Clusia lanceolata Cambess. (Clusiaceae): Anatomical aspects and chemical analysis of essential oil. Flora 208: 165-173.

JOHANSEN DA. 1940. Plant microtechnique, New York: McGraw Hill Book.

JUDD WS, CAMPBELL CS, KELLOGG EA, STEVENS PF AND DONOGHU MJ. 2009. Sistemática Vegetal - Um enfoque filogenético, Editora Artmed.
KLEIN DE, GOMES VM, SILVA-NETO SJ AND DA CUNHA M. 2004. The structure of colleters in several species of Simira (Rubiaceae). Ann Bot 94: 733-740.

LOKVAM J, BRADDOCK JF, REICHARDT PB AND CLAUSEN TP. 2000. Two polyisoprenylated benzophenones from the trunk latex of Clusia grandiflora (Clusiaceae). Phytochemistry 55: 29-34.

MARINI-BETTÒLO GB, NICOLETTI M, PATAMIA M, GALEFFI C AND MESSANA I. 1981. Plant screening by chemical and chromatographic procedure under field conditions. JJ Chromatogr 213: 113-127.

MEDINA E, AGUIAR G, GÓMEZ M, ARANDA J, MEDINA JD AND WINTER K. 2006. Taxonomic significance of the epicuticular wax composition in species of the genus Clusia from Panama. Biochem Sys Ecol 34: 319-326.

MEDINA E, AGUIAR G, GÓMEZ M AND MEDINA JD. 2004. Patterns of leaf epicuticular waxes in species of Clusia: Taxonomical implications. Interciencia 29: 579582.

MENSOR LL, MENEZES FS, LEITÃO GG, REIS AS, DOS SANTOS TC, COUBEL CS AND LEITÃO SG. 2001. Screening of Brazilian plant extracts for antioxidant activity by the use of DPPH free radical method. Phytother Res 15: 127-130.

METCALFE CR AND CHALK L. 1950. Anatomy of dicotyledons: leaves, stem, and wood in relation to taxonomy with notes on economic uses. Oxford: Clarendon Press.

MONTANARI CA AND BOLZANI VS. 2001. Planejamento racional de fármacos baseado em produtos naturais. Quím Nova 24: 105-111.

MOREAU P, BESSOULE JJ, MONGRAND S, TESTET E, VINCENT P AND CASSAGNE C. 1998. Lipid trafficking in plant cells. Prog Lipid Res 37: 371-391.

NOGUEIRA PC, BITTRICH V, SHEPHERD GJ, LOPES AV AND MARSAIOLI AJ. 2001. The ecological and taxonomic importance of flower volatiles of Clusia species (Guttiferae). Phytochemistry 56: 443-452.

NOLDIN VF, ISAIAS DB AND CECHINEL FV. 2006. Gênero Calophyllum: importância química e farmacológica. Quím Nova 29: 549-554.

ODONNE G, VALADEAU C, ALBAN-CASTILLO J, STIEN D, SAUVAIN M AND BOURDY G. 2013. Medical ethnobotany of the Chayahuita of the Paranapura basin (Peruvian Amazon). J Ethnopharmacol 146: 127-153.

OLIVEIRA CMA, PORTO ALM, BITTRICH V AND MARSAIOLI AJ. 1999. Two polyisoprenylated benzophenones from the floral resins of three Clusia species. Phytochemistry 50: 1073-1079.

OLIVEIRA CMA, PORTO ALM, BITTRICH V, VENCATO I AND MARSAIOLI AJ. 1996. Floral resins of Clusia spp.: Chemical composition and biological function. Tetrahedron Lett 37: 6427-6430. 
OLIVEIRA RF, CAMARA CA, AGRA MF AND SILVA TMS. 2012. Biflavonoids from the unripe fruits of Clusia paralicola and their antioxidant activity. Nat Prod Commun 7: 1597-1600.

OPSAHL S AND BENNER R. 1995. Early diagenesis of vascular plant tissues: lignin and cutin decomposition and biogeochemical implications. Geochim Cosmochim Acta 59: 4889-4904.

PAULA JE. 1976. Anatomia de Lorostemon coelhoi Paula, Caraipa valioi Paula e Clusia aff. macropoda Klotzch. Acta Amaz 6: 273-291.

PENG ZF, STRACK D, BAUMERT A, SUBRAMANIAM R, GOH NK, CHIA TF, TAN SN AND CHIA LS. 2003. Antioxidant flavonoids from leaves of Polygonum hydropiper L. Phytochemistry 62: 219-228.

PIETTA PG. 2000. Flavonoids as antioxidants. J Nat Prod 63: 1035-1042.

PORTO ALM, MACHADO SMF, DE OLIVEIRA CMA, BITTRICH V, AMARAL MDCE AND MARSAIOLI AJ. 2000. Polyisoprenylated benzophenones from Clusia floral resins. Phytochemistry 55: 755-758.

PROESTOS C, BOZIARIS IS, NYCHAS G-JE AND KOMAITIS M. 2006. Analysis of flavonoids and phenolic acids in Greek aromatic plants: Investigation of their antioxidant capacity and antimicrobial activity. Food Chem 95: 664-671.

ROCHA DI, DA SILVA LC, PEREIRA EG, SANT'ANNASANTOS BF, GONTIJO ER AND OLIVA MA. 2014. Early detection of injuries in leaves of Clusia hilariana Schltdl. (Clusiaceae) caused by particulate deposition of iron. Rev Árvore 38: 423-432.

RUFINO MSM, ALVES RE, BRITO ES, MORAIS SM, SAMPAIO CG, PÉREZ-JIMÉNEZ J AND SAURACALIXTO FD. 2007. Metodologia Científica: Determinação da atividade antioxidante total em frutas pela captura do radical livre. Comunicado Técnico on Line 127: 1-3.

SANCHO MI, ALMANDOZ MC, BLANCO SE AND FERRETTI FH. 2003. Mechanism of the complexation reaction of aluminium chloride with o-hydroxybenzophenone. J Mol Struct 634: 107-120.

SANT'ANNA-SANTOS BF, THADEO M, MEIRA RMSA AND ASCENSÃO L. 2006. Anatomia e histoquímica das estruturas secretoras do caule de Spondias dulcis Forst. (Anacardiaceae). Rev Árvore 30: 481-489.

SCHNEIDER SZ. 1985. Anatomia foliar de Clusia hilariana Schlechtendal e Clusia spiritu-sanctensis G. Mariz et Weinberg (Guttiferae) ocorrentes no estado do Espírito Santo. Tese de Mestrado, Universidade Federal do Rio de Janeiro, Brasil. (Unpublished).

SEO EK, HUANG L, WALL ME, WANI MC, NAVARRO H, MUKHERJEE R, FARNSWORTH NR AND KINGHORN AD. 1999. New biphenyl compounds with DNA strand- scission activity from Clusia paralicola. J Nat Prod 62: 1484-1487.

SEYOUM A, ASRES K AND EL-FIKY FK. 2006. Structureradical scavenging activity relationships of flavonoids. Phytochemistry 67: 2058-2070.

SILVA C, LEITE K, FERREIRA L, SILVA M AND SILVA L. 2014. Influência da altitude na plasticidade foliar de Clusia obdeltifolia Bittrich (Clusiaceae). Rev Nordest Biol 23: 29-48.

SILVA LC, OLIVA MA, AZEVEDO AA, ARAÚJO JM AND AGUIAR RM. 2005. Micromorphological and anatomical alterations caused by simulated acid rain in restinga plants: Eugenia uniflora and Clusia hilariana. Water Air Soil Pollut 168: 129-143.

SILVA MC AND PAIVA SR. 2012. Antioxidant activity and flavonoid content of Clusia fluminensis Planch. and Triana. An Acad Bras Cienc 84: 609-616.

SILVA MCA, HERINGER AP, FIGUEIREDO MR AND PAIVA SR. 2012. Separation of clusianone from Clusia fluminensis Planch. and Triana (Clusiaceae) by High Speed Counter-Current Chromatography (HSCCC). J Liq Chrom Relat Tech 35: 2313-2321.

SOUSA CMM ET AL. 2007. Fenóis e atividade antioxidante de cinco plantas medicinais. Quím Nova 30: 351-355.

STEVENS PF. 2007. Clusiaceae-Guttiferae. In: Kubitzki K (Ed), Flowering plants. Berlin, Springer, p. 48-66.

TAVARES LHC, BRITO RGL, GUILHON GMSP AND CONSERVA LM. 2001. Terpenóides e xantonas de Tovomita brasiliensis Walp. (Guttiferae). Rev Virtual de Iniciação Acadêmica da UFPA 1: 1-7.

VALADEAU C ET AL. 2009. Medicinal plants from the Yanesha (Peru): evaluation of the leishmanicidal and antimalarial activity of selected extracts. J Ethnopharmacol 123: 413-422.

VAN ACKER SA, VAN DEN BERG DJ, TROMP MN, GRIFFIOEN DH, VAN BENNEKOM WP, VAN DER VIJGH WJ AND BAST A. 1996. Structural aspects of antioxidant activity of flavonoids. Free Radic Biol Med 20: 331-342.

VIRGINIO MCAS. 2015. Quimiossistemática do Gênero Clusia L. e Prospecção Químico-Biológica de Clusia fluminensis Planch. \& Triana e Clusia lanceolata Cambess. (Clusiaceae). Tese de Doutorado. Universidade Federal do Rio de Janeiro, 208 p.

WAGNER HM, BLADT S AND ZGAINSKI EM. 1984. Plant Drug Analysis, New York: Springer-Verlag.

WITTSTOCK U AND GERSHENZON J. 2002. Constitutive plant toxins and their role in defense against herbivores and pathogens. Curr Opin Plant Biol 5: 300-307. 